\title{
Multi-stakeholder processes to strengthen policies for small and medium-scale forestry enterprises in Indonesia
}

\author{
H. PURNOMO a,b, R. ACHDIAWAN ${ }^{b}$, B. SHANTIKO ${ }^{c}$, S.M. AMIN ${ }^{d}$, R.H. IRAWATIe, MELATI ${ }^{f}$ and D.A. WARDELL ${ }^{b}$ \\ ${ }^{a}$ Faculty of Forestry, Bogor Agricultural University, Bogor Indonesia \\ ${ }^{b}$ Center for International Forestry Research (CIFOR), Bogor Indonesia \\ ${ }^{c}$ United Nations Industrial Development Organization (UNIDO), Jakarta, Indonesia \\ ${ }^{d}$ Jepara Small-scale furniture association (APKJ), Jepara, Indonesia \\ ${ }^{e}$ Re-Mark Asia, Indonesia \\ ${ }^{f}$ Australian National University (ANU), Canberra
}

Email: h.purnomo@cgiar.org, r.achdiawan@cgiar.org,b.shantiko@unido.org, sultanjepara@yahoo.com, rini.irawati@re-markasia.com, melati_1984@yahoo.com and a.wardell@cgiar.org

\begin{abstract}
SUMMARY
The furniture industry is the most labor-intensive and the most important forest industry for small and medium-sized enterprises (SMEs) in Indonesia. Power imbalances among actors participating in furniture value chains jeopardize the sustainability of the furniture industry. Regional and global trade agreements could worsen the situation of SMEs. From 2008 to the present, participatory action research (PAR) was conducted on furniture value chains in Jepara District to develop a ten year strategic roadmap. The multi-level governance (MLG) involves complex interactions of state, private and civil society actors at various levels, and institutions linking higher levels of social and political organization. The multi-year roadmap process facilitated a more complex approach to MLG which led to a better understanding of how policies work as instruments of governance within systems of power and authority. The roadmap process strengthened small-scale producers' bargaining positions and improved trust with local government authoritiesto achieve sustainable development goals.
\end{abstract}

Keywords: Furniture, participatory action research, politics, Jepara, district law

Processus à parties prenantes multiples pour fortifier la politique des entreprises forestières de moyenne et petite échelle en Indonésie

\section{H. PURNOMO, R. ACHDIAWAN, B. SHANTIKO, S.M. AMIN, R.H. IRAWATI, MELATI et D.A. WARDELL}

L'industrie du meuble est la plus intensive du point de vue du travail et le secteur le plus important de l'industrie forestière pour les entreprises de petite et moyenne échelle (SMEs) en Indonésie. Des déséquilibres de puissance entre les acteurs participant dans les chaînes de valeur du mobilier mettent en péril la durabilité de l'industrie du meuble. Les accords de commerce régionaux et globaux pourraient faire empirer la situation des SMEs. Une recherche à action participative (PAR) a été conduite sur les chaînes de valeur du meuble dans le district du Jepara afin de développer une carte stratégique sur dix ans. La gestion à plusieurs niveaux (MLG) comprend des interactions complexes entre les acteurs d'état, de société civile et privés à divers niveaux, ainsi que des institutions reliant les hautes strates d'organisations sociales et politiques. Le processus de plan à travers les ans facilitait une approche plus complexe à la MLG qui conduisait à une meilleure compréhension de la manière dont les politiques fonctionnent en tant qu'instruments de gestion au sein des systèmes de puissance et d'autorité. Ce processus de planification renforçait les positions de marchandage des petits producteurs et encourageait une attitude de confiance dans le fait que les autorités gouvernementales locales puissent aboutir à des buts de développement durable.

Los procesos de múltiples partes interesadas para fortalecer las políticas para las empresas forestales de pequeña y mediana escala en Indonesia

\section{H. PURNOMO, R. ACHDIAWAN, B. SHANTIKO, S.M. AMIN, R.H. IRAWATI, MELATI y D.A. WARDELL}

En Indonesia, la industria del mueble es la más intensiva en cuanto a mano de obra y la industria forestal más importante para las pequeñas y medianas empresas (PYME). Los desequilibrios de poder entre los actores que participan en las cadenas de valor del mueble ponen en peligro la sostenibilidad de esta industria. Las políticas regionales como las de la Comunidad Económica de la Asociación de Naciones del Sudeste de Asia (ASEAN) y del Tratado de Libre Comercio ASEAN-China podrían empeorar la situación de las PYME, si no se fortalecen. Desde 2008 hasta la actualidad, se ha venido realizando investigación-acción participativa (IAP) para las cadenas de valor del mueble de la teca y la caoba en el Distrito de Jepara, para desarrollar un plan estratégico de diez años para el sector. La gobernanza de nivel múltiple (GNM) de los recursos 
forestales -que son la materia prima básica para la industria del mueble- implica interacciones complejas entre el Estado, los actores privados y la sociedad civil a diversos niveles, y las instituciones que vinculan los niveles más altos de organización social y política. Las PYME y las comunidades locales en el Distrito de Jepara están cada vez más conectadas a las redes e influencias globales. Esto crea nuevas oportunidades para aprender y abordar los problemas, pero también puede introducir nuevos riesgos y presiones. El proceso del plan estratégico de varios años facilitó un planteamiento más complejo para la GNM que llevó a un mejor entendimiento entre las partes interesadas acerca del funcionamiento de las políticas como instrumentos de gobernanza y la organización de las PYME y las comunidades dentro de los sistemas de poder y autoridad. El proceso del plan estratégico fortaleció las posiciones de negociación de los productores de pequeña escala y mejoró la confianza en las autoridades del gobierno local. El uso de la IAP para mejorar la equidad en las industrias forestales se puede aplicar también en otras partes del mundo para alcanzar los Objetivos de Desarrollo Sostenible (ODS) de las Naciones Unidas.

\section{INTRODUCTION}

Furniture making is the most labour-intensive industry in the forestry sector. In 2011, the global furniture trade accounted for US\$ 135 billion, or about $1 \%$ of the world trade in manufactured goods. Approximately, 54\% of furniture exports are from developing countries (ITTO 2006). All middle-income countries, e.g. Indonesia, Malaysia and Brazil show strong comparative advantages in terms of labour and material costs and solid timber material provisions. However, their competitiveness index has declined slightly in recent years (Han et al. 2009). Furthermore, Purnomo et al. (2009) revealed that overseas actors enjoyed more value added than domestic actors, and finishing and exporting companies make a bigger profit than small and medium-sized enterprises (SMEs) and tree growers.

Teak (Tectona grandis Linn) is the most sought after tropical hardwood due to its strength, cultural and aesthetic value. More than $90 \%$ of the world's teak grows in South and Southeast Asia in natural forests, amounting to 29.035 million hectares, and plantation forests amounting to 4.436 million hectares. Teak only grows naturally in Myanmar, India, the Lao People's Democratic Republic and Thailand (Kollert and Cherubini 2012). However, the teak plantation area in Java, Indonesia, is more than 1 million hectares; wood from these plantations is mostly used for high quality furniture.

SMEs play an important role in the furniture sector. About $95 \%$ of the furniture made involves SMEs. The livelihoods of millions of people in Java depend on the furniture industry and its chains (Ewasechko 2005). However, power imbalances among SMEs and large enterprises (LEs) jeopardize the sustainability of the furniture industry in the long term. In addition, the establishment of the ASEAN-China Free Trade Agreement (ACFTA) and the ASEAN Economic Community (AEC) coupled with decreasing export revenues could aggravate the situation of small-scale producers. Policies that sustain and strengthen the furniture industry and promote SMEs are urgently needed.

This paper describes the development of a roadmap (or strategic plan) for the furniture industry in Jepara District, central Java, Indonesia. Finding agreement on a common future for both large and small furniture manufacturers is never an easy task. As in other developing countries, the role of government in Indonesia is critical. However, local government lacks experience in facilitating participatory and multi-stakeholder processes. This action research is of interest because it is the first in Indonesia to directly involve district-level authorities and SMEs in the development of a clear and performance-based roadmap. The roadmap was also unique in being dedicated solely to the furniture industry.

\section{CONTEXT AND METHODS}

\section{Context}

Furniture is one of the four biggest non-oil and gas exports of Indonesia. The others are palm oil, footwear and rubber. The majority of players in the Indonesian furniture industry are SMEs, who contribute a significant amount to the national income (Yoshino and Taghizadeh-Hesary 2015). Furniture's contribution can be seen from the export volume, which is continuously growing. According to COMTRADE (2016), the export value of wooden furniture in 2014 was US\$1.1 billion.

Jepara is the centre of the furniture industry in Indonesia. In 2011, there were at least 11,981 furniture workshops, showrooms and warehouses in Jepara District (Achdiawan and Puntodewo 2011). The furniture industry processes 0.9 million cubic meters of wood per year, and contributes about $26 \%$ of Jepara District's total economy. However, export volumes and values, as well as employment are declining in the sector. The industry mostly produces low valueadded products and is categorized as a 'sunset industry' by the government. The size of the industry is decreasing for both SMEs and Large Enterprises (LEs). SMEs are disproportionately affected given the nature of small-scale family-based subsistence operations, low capital outlays and limited access to new markets. The distribution of furniture enterprises in Jepara is shown in Figure 1.

The Jepara furniture industry increasingly faces problems due to a general scarcity of raw materials and fierce competition from China and Vietnam in both domestic and international markets. Illegal logging in state-owned forest companies in Java (Perhutani), has reduced the availability of wood, particularly teak and mahogany. China mass produces good quality, low price furniture, while Vietnam is a newcomer that is growing rapidly. The onset of the ACFTA which started in 2012 has made competition even tougher than before.

Purnomo et al. (2011) provide details on value chains of furniture in Jepara, as shown in Figure 2. The chains flow from the bottom to the top. There are four types of chains 
FIGURE 1 Furniture business unit distribution, both SMEs and LEs, in District of Jepara (inset Indonesia)

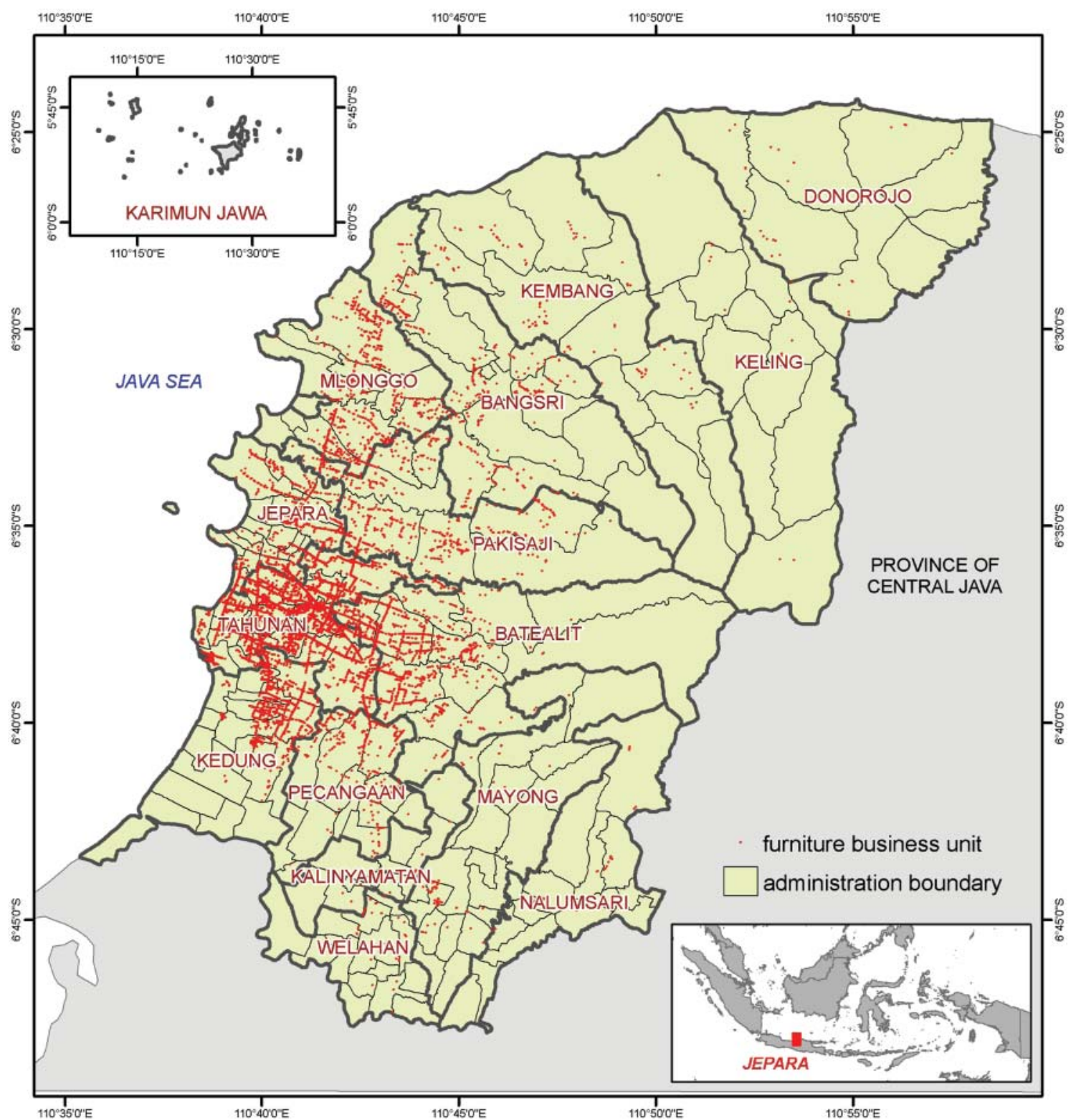

between those who are connected in furniture business. First, Market-based, indicated by many customers and many suppliers; repeat transactions possible, but information flows limited; and no technical assistance. Second, Balanced network, indicated by supplier having various customers; intense information flow in both directions; and both sides have capabilities and commitment to solve problems through negotiation. Third, Directed network, indicated by main customer takes at least $50 \%$ of output; customer defines the product and provides technical assistance; and imbalance of information. Fourth, Hierarchy, indicated by vertical integration; supplying establishment owned by customer; and very limited autonomy to take decisions at the local level.

The chain between finishing companies/exporters and small-scale producers is hierarchy. Small-scale producers are involved in a directed network relationship with domestic brokers. The relations between small-scale producers, sawmill owners and wood retailers are of a market-based type. Small-scale producers can freely buy wood from retailers. However, if they do not have sufficient funds, they can also take loans from nearby wood retailers. They are also free to choose which sawmill actually saws their logs. The relation between wood retailers and tree growers is also a directed network. With about 1 million hectares of teak plantations, the state-owned forest company, Perhutani, has more control and power than wood retailers, as it determines pricing and quality. Small-scale community-based agroforests as an alternative source of wood are less influential and powerful than wood retailers (Purnomo et al. 2003b).

The governance between small-scale producers and finishing companies/exporters is hierarchical in nature. This value chain leaves SMEs in a weak position in comparison 
FIGURE 2 Value chain governance that involves small-scale producers (Purnomo et al. 2011)

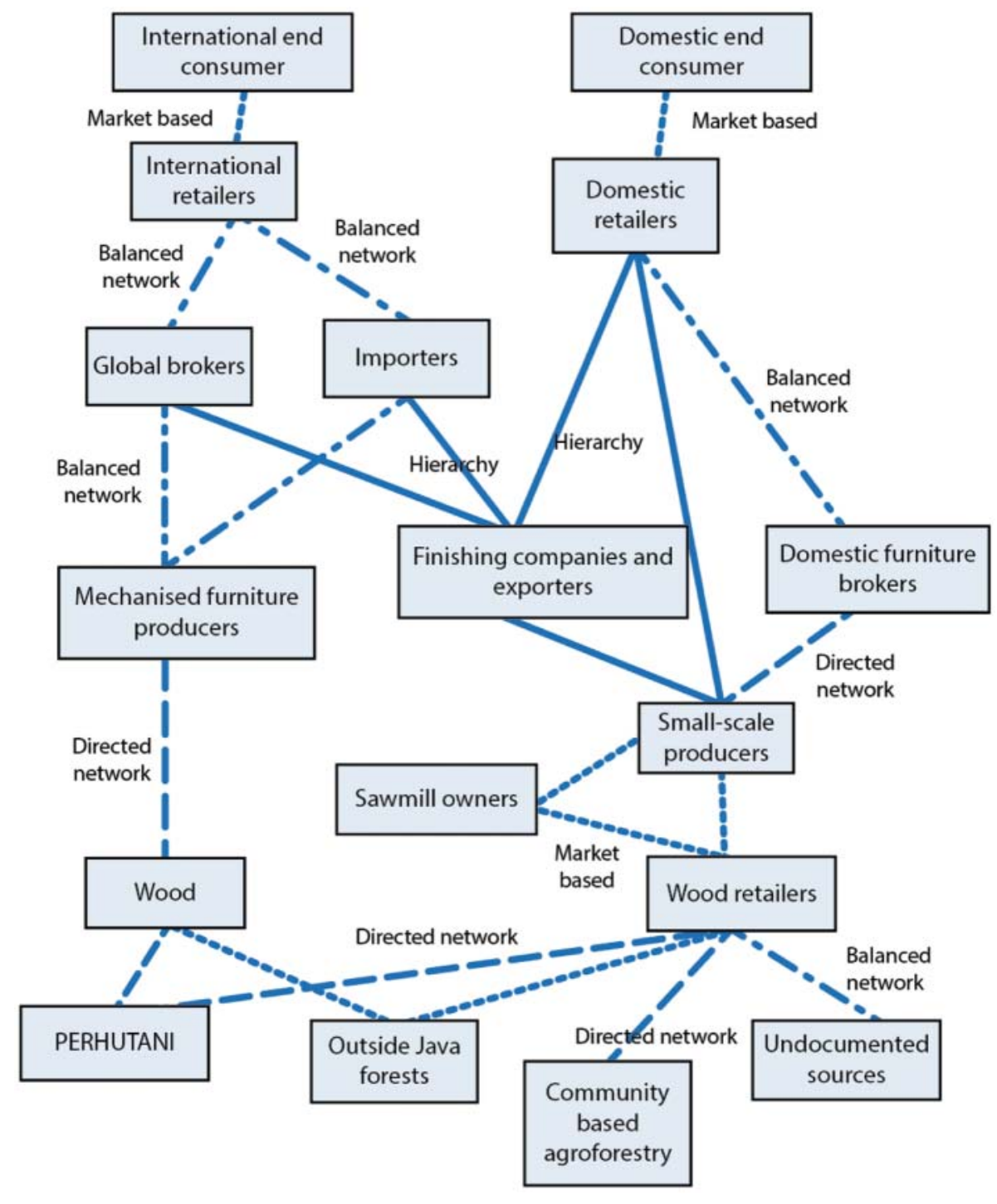

with large enterprises LEs. It is the finishing companies that interact with global buyers about the furniture designs and specifications which are then given to LEs and SMEs depending on the size of orders. Global buyers are usually subsidiaries of overseas retailers and hence, orders are driven by importers and global brokers in a directed network relationship with international retailers.

\section{Method}

The development of the Jepara District furniture roadmap was carried out using Participatory Action Research (PAR). PAR is an inclusive process through which members of a community identify a problem, collect and analyze information, and act to find solutions and to promote social and political transformations (Selener 1997). These transformations are also used to improve the adaptive and collaborative capacity of local communities, as defined by Colfer (2005). Through PAR, the local communities are able to act collectively and participate in decision making processes involving their forest and lands.

We conducted the PAR through the following steps: (a) Identifying problems and stakeholders; (b) collecting and analyzing information; (c) multi-stakeholder workshops to develop the draft roadmap; and (d) augmenting the roadmap to both political elites and policy makers. Figure 3 provides the framework of the research from the problem definition to the augmenting roadmap. The implementation and monitoring of the roadmap would not be part of this paper.

Stakeholder identification was conducted using the Who Counts matrix (Colfer et al. 1999). This matrix scores each stakeholder between 1 (low) and 5 (high). Non-linear principal component analysis, namely correspondence analysis, was implemented to map stakeholders in a two-dimensional diagram. Correspondence analysis is usually defined as a pair of principal component analyses, one for the rows and one for the columns, where each set of profiles defines a 'cloud' of points in multi-dimensional space, where the points 
FIGURE 3 The framework of research

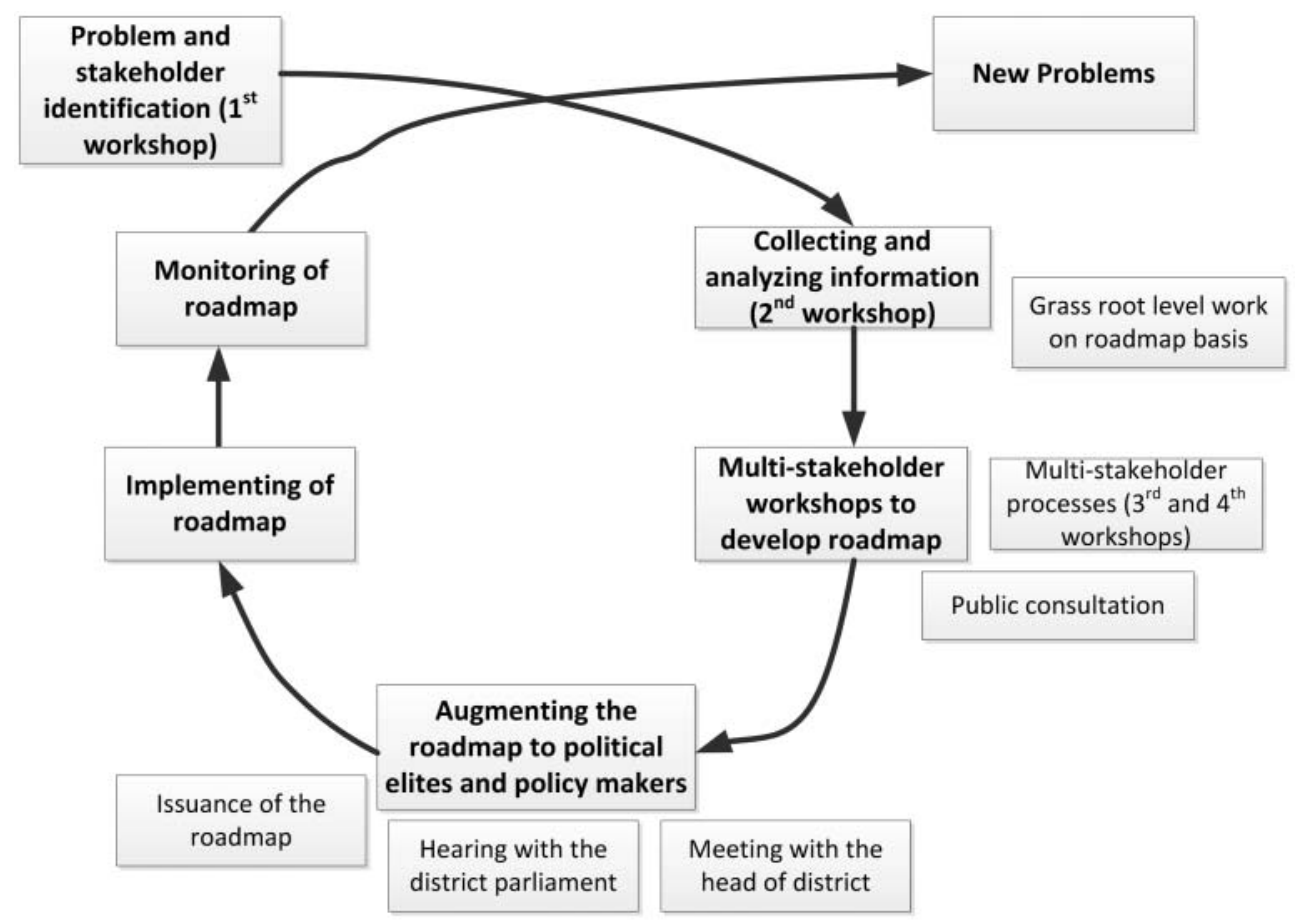

are weighted by their respective masses, and, where distances and scalar products are defined in terms of the respective $\times 2$ metric (Greenacre 1993). This correspondence analysis result was used to understand the relative position of each stakeholder to others in terms of, for examples, level of power in influencing policy making processes, level of furniture manufacturing knowledge and degree of livelihood dependency on forestry business (Purnomo et al. 2012).

The closeness of the stakeholder and variables indicates the strength of the variables to characterise the actor. The correspondence analysis plot is generated from the table of stakeholders vs. variables and detect their relations (Gower and Hand, 1996) from the non-linear data. The analysis was run by using Multivariate Statistical Package version 3.13. The accumulative percentage of variance explained by 2 latent components shows the strength of the model, in most cases, $75 \%$ is the threshold.

The roadmap was developed using a multi-stakeholder process encompassing four consecutive workshops each of which ensured that all stakeholders were able to freely communicate their interests and concerns (Habermas 1987). This participatory research was conducted by a furniture value chain (FVC) team, which comprised 15 people from Jepara District furniture stakeholders, 4 people from the Center for International Forestry Research (CIFOR), 2 people from Bogor Agricultural University (IPB), 2 people from the Forestry Research and Development and Innovation Agency (FORDA) of the Ministry of Environment and Forestry and 5 people from Jepara District Government (PEMDA). The FVC office, located in the Jepara Trade and Tourism Centre facilitated research activities and stakeholder engagement.

\section{RESULTS}

\section{Problem and stakeholder identification}

Stagnant furniture exports, at around US\$110 million/year, raised concerns among Jepara business actors and government. The financial crisis in 2008 and fierce competition from Chinese and Vietnamese furniture producers also made exports more difficult. SMEs indicated that they received unfair value added compared with LEs. A shortage of wood materials due to illegal logging during the post-1998 political crisis and inefficient wood use raised many questions about the sustainability of Jepara District's furniture industry. The lack of a concerted strategic plan for a local furniture industry was raised by various actors including government, SMEs, LEs, non-governmental organizations (NGOs) and community colleges despite earlier national initiatives.

The Indonesian Ministry of Industry issued Ministerial Regulation No. 119/M-IND/10/2009 on the Development of the Furniture Industry Cluster Roadmap as an instrument under the Presidential Regulation No. 28/ 2008 regarding the National Industry Policy. However, there was no clear implementation in Jepara nor any strategic plan for developing the furniture industry.

CIFOR, in collaboration with IPB and FORDA, carried out a FVC action research project funded by the Australian Centre for International Agricultural Research (ACIAR) during the period 2008-13, and subsequently by DFID-UK (Department for International Development of United Kingdom) in 2014-17). The goals were to improve the sustainability of the furniture industry in Jepara District and improve the 
livelihoods of SMEs. A first scoping workshop was held on 23 December 2010 with the aim of sharing initial ideas on existing policies by different institutions affecting the furniture industry. Understanding current policies was fundamental to making improvements for the future. During the 1-day workshop, presentations were made by the Jepara Government Development Planning Agency (BAPPEDA), the Industry and Trade Government Unit (INDAG), Jepara Small and Medium-scale Enterprises Government Unit (UKM), the state-owned forest company (Perhutani), the Jepara Business and Commerce Association (KADIN), the Jepara Furniture Industry and Handicraft Association (ASMINDO) and the Jepara Small-scale Producer Association (APKJ). Each presentation was followed by a discussion. At the end of the workshop, a plenary discussion was facilitated by the CIFOR team.

BAPPEDA, as district planning development agency, mentioned that the national roadmap had to be elaborated further to be appropriate at the local level. Likewise, every local regulation must be derived from, or aligned with national regulations. The local roadmap is necessary for developing action programs to improve the role of the private sector in increasing competitiveness, developing unique products and winning market competition, as well as sustaining the profitability of SMEs.

ASMINDO, the association of furniture (mostly for LEs), stated that producers need to innovate and develop new furniture products to meet market demand. The strength of Jepara is handmade products and fancy arts. The weakness lies in its inefficiency, lack of standardized products, weak support in research and development, and a lack of a database for market intelligence and promotion. These all need to be addressed as part of a comprehensive plan such as a roadmap.

As part of the Jepara Government responsible for industry and trade, INDAG outlined the basic problems experienced by the Jepara furniture industry, which mainly concern the availability of raw materials, quality of design and products, and the emergence of new competitors. The Forestry District Unit (DISHUT) urged the development of all district government regulations to involve all stakeholders, including those in the retail wood trade and tree growing. The APKJ underlined the need to solve small-scale producer problems, such as improving their capacities to manufacture quality furniture.

The first or scoping workshop concluded that there were two main unaddressed and equally important problems in Jepara. All stakeholders needed to work together in (a) the stagnant of furniture industry in Jepara; and (b) weak performance of SMEs. Moving forward, it was agreed that: (a) Jepara needs a blue print for their furniture industry; (b) Jepara needs strong leadership; and (c) further workshops were needed, focusing solely on the furniture industry, to follow up on the initial the results. The scoping workshop participants had been identified by the FVC team in discussion with BAPPEDA and APKJ. The workshop participants demanded to extent the workshop participants which reflected the need for more stakeholders to be involved in the roadmap development process.
Stakeholders were selected after the scoping workshop using the following criteria: i. livelihoods dependent on the furniture industry; ii. exercising a degree of power or influence in the furniture business; iii. having a degree of power in policy-making processes (e.g. the national and local governmental administrative systems); iv. having political power (e.g. political parties, allies) and v. technical knowledge or expertise in manufacturing furniture. These criteria were agreed by the scoping workshop participants.

The full list of stakeholders is presented in Annex 1. Table 1 provides the scores for each stakeholder selected using the aforementioned criteria. The scores were derived from the perspective of FVC team with the inputs from the scoping workshop participants. The four most powerful stakeholders are ASMINDO, Bupati (Head of District), District Parliament and Perhutani.

Figure 4 provides a correspondence analysis of stakeholders, which indicates the strengths, and profile of each stakeholder. We can see clearly a polarizing of actors based on: (1) Political power and business as one group; (2) power in policy making alone as a separate group; (3) livelihood dependency on the furniture industry, and (4) Knowledge on furniture and business as another group. These four groups of actors are represented by four quadrants in Figure 4. The model is quite strong, with $78 \%$ of variance is explained by the model. The two dimension plot in Figure 4 represents the constellation of the stakeholders in Jepara and their interest and role in the furniture industry.

The private sector and small-scale enterprises, i.e. APKJ, HPKJ, ASEPHI and FRK, are relatively closely grouped. They rely on the furniture industry and have good knowledge of wooden furniture and crafts. STIENU, STTDNU and SMIK are grouped as educational bodies that have good knowledge and are relatively dependent on the furniture industry. The DRD also has good knowledge of the industry but is not directly reliant upon it.

As the large-scale furniture producers' association, ASMINDO's members are somewhat dependent upon the furniture industry, but at the same time have access to business and political channels. Hence, ASMINDO is located strategically in terms of knowledge of the industry and power to influence policies. Another private-sector actor that has access to business and political power is KADIN, which interestingly is less dependent upon the furniture business. Furniture is one of KADIN's interests, however, it is not the only one. Clearly, government bodies such as the Bupati Office, District Parliament and Perhutani are standing on the same axis, where they have power in business, power in politics and power in policy making. Perhutani's power in business and policy making is related to raw materials, e.g. defining wood prices. Perhutani is a state-owned forest enterprise that supplies high quality wood, mainly teak, to the furniture industry. Their role in defining raw material prices is very significant in influencing the furniture industry in general.

Other government bodies, i.e. Dinas UKM, INDAG, Dinas Kehutanan and BAPPEDA, stand in different corners. They are authorized to make policy, but are less powerful than the Bupati and do not necessarily have access to political 
TABLE 1 Identified stakeholders and their scores $(1=$ lowest to $5=$ highest $)$

\begin{tabular}{|c|c|c|c|c|c|c|c|c|}
\hline & Stakeholder/cri & iterion & Power in & $\begin{array}{c}\text { Power in } \\
\text { policy-making }\end{array}$ & Political & $\begin{array}{l}\text { Knowledge on } \\
\text { furniture and }\end{array}$ & Livelihood & Score \\
\hline 1 & BAPPEDA & $\begin{array}{l}\text { Regional Planning and } \\
\text { Development Board }\end{array}$ & 1 & 5 & 4 & 3 & 1 & 3 \\
\hline 2 & KADIN & $\begin{array}{l}\text { Chamber of Commerce and } \\
\text { Industry }\end{array}$ & 4 & 3 & 4 & 4 & 3 & 3 \\
\hline 3 & ASMINDO & $\begin{array}{l}\text { Furniture Industry and } \\
\text { Handicraft Association }\end{array}$ & 5 & 3 & 4 & 5 & 5 & 5 \\
\hline 4 & FEDEP & $\begin{array}{l}\text { Forum for Economic } \\
\text { Development and } \\
\text { Employment Promotion }\end{array}$ & 2 & 2 & 2 & 3 & 2 & 2 \\
\hline 5 & HIPMI & $\begin{array}{l}\text { Indonesian Young } \\
\text { Entrepreneurs Association }\end{array}$ & 2 & 2 & 2 & 3 & 3 & 2 \\
\hline 6 & APKJ & $\begin{array}{l}\text { Jepara Furniture Small-scale } \\
\text { Producer Association }\end{array}$ & 3 & 2 & 3 & 4 & 5 & 3 \\
\hline 7 & HPKJ & $\begin{array}{l}\text { Jepara Wood Trader } \\
\text { Association }\end{array}$ & 3 & 2 & 3 & 4 & 5 & 3 \\
\hline 8 & STIENU & $\begin{array}{l}\text { Higher School of Economics } \\
\text { Nahdlatul Ulama }\end{array}$ & 1 & 1 & 1 & 4 & 3 & 1 \\
\hline 9 & STTDNU & $\begin{array}{l}\text { Higher School of Design } \\
\text { Technology Nahdlatul } \\
\text { Ulama }\end{array}$ & 1 & 1 & 1 & 5 & 4 & 1 \\
\hline 10 & SMIK & High School & 1 & 1 & 1 & 5 & 4 & 1 \\
\hline 11 & $\begin{array}{l}\text { District } \\
\text { Parliament }\end{array}$ & $\begin{array}{l}\text { District Parliament, } \\
\text { Commission B }\end{array}$ & 4 & 5 & 5 & 3 & 3 & 4 \\
\hline 12 & ASEPHI & $\begin{array}{l}\text { Handicraft Exporter and } \\
\text { Producer Association }\end{array}$ & 2 & 2 & 3 & 4 & 5 & 3 \\
\hline 13 & FRK & Clusters Discussion Forum & 1 & 1 & 1 & 3 & 5 & 1 \\
\hline 14 & IWAPI & $\begin{array}{l}\text { Indonesian Women } \\
\text { Entrepreneur Association }\end{array}$ & 3 & 2 & 2 & 3 & 3 & 3 \\
\hline 15 & INDAG & $\begin{array}{l}\text { District Industry and Trade } \\
\text { Office }\end{array}$ & 3 & 5 & 1 & 4 & 2 & 3 \\
\hline 16 & Dinas UKM & $\begin{array}{l}\text { District Small-scale } \\
\text { Enterprises Office }\end{array}$ & 3 & 5 & 1 & 4 & 2 & 3 \\
\hline 17 & DISHUT & District Forestry Office & 2 & 5 & 1 & 3 & 2 & 2 \\
\hline 18 & PERHUTANI & $\begin{array}{l}\text { State Owned Forest } \\
\text { Enterprise }\end{array}$ & 5 & 4 & 3 & 4 & 3 & 4 \\
\hline 19 & $\begin{array}{l}\text { LAKPESDAM } \\
\text { NU }\end{array}$ & $\begin{array}{l}\text { Human Resources Research } \\
\text { and Development Agency of } \\
\text { Nahdlatul Ulama }\end{array}$ & 1 & 1 & 3 & 2 & 1 & 1 \\
\hline 20 & DRD & District Research Council & 1 & 1 & 1 & 5 & 1 & 1 \\
\hline 21 & Bupati & & 5 & 5 & 5 & 3 & 3 & 5 \\
\hline
\end{tabular}

power. Some educational bodies oppose the political and business power corner. The remaining stakeholders, i.e. FEDEP, HIPMI and IWAPI, are less significant players in the furniture business but they have power in business and expertise in the furniture industry. LAPESDAM NU stands alone as a unique body that has power in politics, as NU's work unit; it is the biggest Islamic organization in Indonesia, particularly in Jepara. Jepara is a district where NU based political parties such as United Development Party (PPP) and National Awakening Party (PKB) win the local election. 
FIGURE 4 Correspondence analysis of stakeholders symbolised with rectangle and their position and roles symbolised with triangle (variance $=78 \%$ )

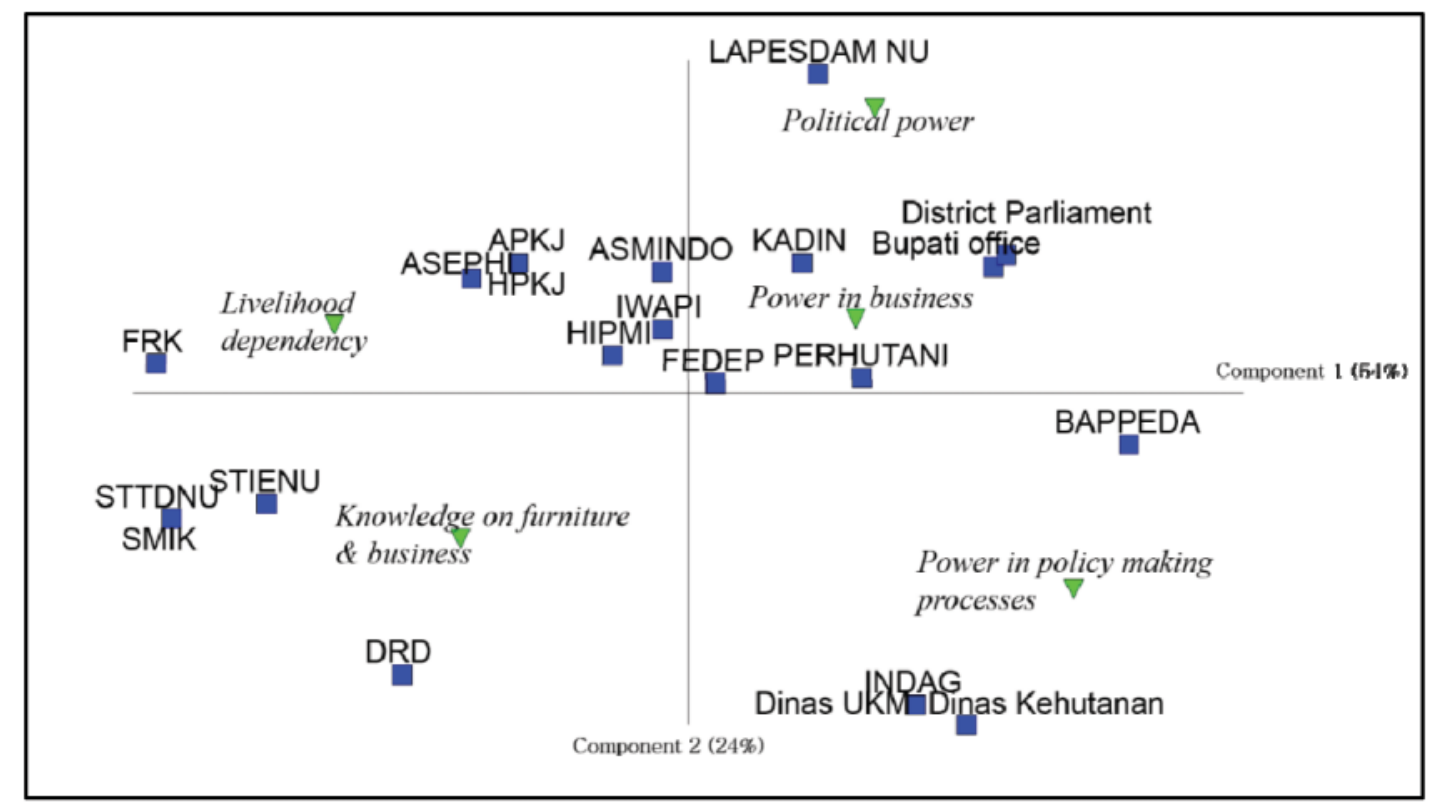

Interestingly, those who have power to influence regulations and politics do not necessarily have expertise in furniture and business, and their livelihoods are also less dependent on the industry. Therefore, when regulations are set solely by the political power and policy makers, they may not adequately recognize or incorporate the views of direct beneficiaries such as SMEs. Regulations often miss the fundamental problems (Situmorang and Kartodihardjo 2013). In order to harmonize this, policy making has to involve all stakeholders who represent different strengths and needs. The Roadmap of the Jepara Furniture Industry follows this process. All stakeholders were actively involved in order to develop the concept and raise concerns. District parliament and local governments are downstream of the process. They are able to transcribe all the needs documented and synthesized in the roadmap into local government regulations.

\section{Collect and analyse information, and find solutions}

All stakeholders listed in Table 1 were invited to the second workshopon 8-9 March 2011; 36 people participated. The aim was to collect and analyse information from various actors and interests, and identify existing and/or potential solutions. Participants shared their ideas and raised questions for discussion. BAPPEDA elaborated on the vision for Jepara by 2030 , as well as the national roadmap for the furniture industry 2010-2014. As there was no existing roadmap at the district level, the workshop was extremely important for strengthening the Jepara District furniture industry. CIFOR also outlined possible methods for conducting the workshop.

ASMINDO explained that furniture in Jepara was a craft or home industry, therefore China was not the main competitor because China mostly produce machinery-based furniture. However, Malaysia is a strong competitor. Furniture is also a buyer-driven product, which means buyers' willingness to pay drives the industry; this is also true for certified furniture, when it comes to premium prices. IWAPI explained that women in Jepara are mostly involved in handicrafts, and face problems in accessing capital funding and in marketing their products.

On the second day of the workshop, the FVC team presented the SWOT (Strengths, Weaknesses, Opportunities and Threats) analysis results for the Jepara furniture industry (see section 3.3.1), followed by a description of the results of a gap analysis by IPB. This compared current and possible future scenarios. The FVC team also shared their vision, mission and possible long-term actions plans. APKJ proposed possible actions for the next 10 years, including a suggestion that a large proportion of the district government budget should be allocated to small-scale producers.

The stakeholders agreed that a district roadmap is a strategic solution for all problems identified in the furniture industry. In the previous workshop, it had been referred to as a 'blueprint', which was then renamed 'roadmap' to align with the national regulations. The roadmap would comprise a high-level plan for the Jepara furniture industry to reach its goals. It was also suggested that the roadmap become a District Law or PERDA (Peraturan Daerah) instead of a Head of District Regulation or PERBUP (Peraturan Bupati). PERDA is binding law at district level and needs to be agreed by district government and parliament. It is much stronger than PERBUP. The hope was that the roadmap would be the 'rules of the game' for all actors and be implemented once it has been developed. 


\section{Outputs and Outcomes}

\section{Grass root level work on roadmap basis}

The imbalance of power relations among actors participating in teak FVCs in Jepara District informed us that APKJ representatives could not be introduced into the multi-stakeholder process at the beginning of the roadmap development. Otherwise, they would be stifled and unable to express their ideas and concerns freely. Every effort was made to address such imbalances of during the roadmap development process. If left unaddressed, larger and more influential actors and LEs including the district government, finishing companies, brokers and exporting companies would have dominated the discussions at each stage in the process.

APKJ, as an association of small-scale furniture producers, represents the interests of about 11,000 small-scale producers. APKJ was interested in having a roadmap that provided more opportunities for them to participate in decision-making processes and to facilitate improvements in furniture quality, marketing and capital access. Through focus group discussions (FGDs), APKJ and the FVC team collected ideas and initiatives for the roadmap. We came up with a list of ideas to ensure SMEs are counted in the future of furniture industry development. The ideas, among others, were to: (a) Allocate a larger proportion of the government budget for SME development; (b) build government-funded training centres; (c) facilitate marketing of SME products; (d) provide low-interest credit for SMEs; and (e) establish governmentfunded wood depot to allow SME to obtain wood at an affordable price. We collected and elaborated ideas, which then became the basis of the roadmap.

A SWOT analysis was conducted to develop a first draft for the roadmap. A SWOT analysis is a structured planning method used to evaluate the strengths, weaknesses, opportunities and threats in the furniture business in Jepara. The SWOT matrix is shown in Figure 5. Based on this figure, we developed the first roadmap draft, which consists of problems, competitive advantages, SWOT analysis, strategy and policy, and a 10-year program of actions.

\section{Multi-stakeholder process in roadmap development}

All stakeholders (Table 1) participated in the third workshop on 13 July 2011. The aim of the workshop was to discuss the structure and content of the roadmap. The FVC team and FORDA presented ideas on the roadmap, followed by a questions and answers session. The District Head or Bupati of Jepara attended the workshop, listened and commented on the roadmap. He fully welcomed and supported the idea.

Facilitated by members of the FVC project advisory group, workshop participants suggested the roadmap include more local orientation and data rather than presenting a national perspective. The agreed roadmap 2013-2023 structure

FIGURE 5 SWOT analysis of the Jepara District furniture industry

\begin{tabular}{|c|c|}
\hline \multicolumn{2}{|c|}{ Internal factor } \\
\hline Strength & Weakness \\
\hline $\begin{array}{l}\text { Human resources enhanced by carving } \\
\text { talents and skills } \\
\text { - The availability of labour supply in the } \\
\text { furniture industry } \\
\text { - The establishment of an association of } \\
\text { small-scale furniture producers (APKJ) } \\
\text { - Strong support from district head through a } \\
\text { Memorandum of Understanding (MoU) } \\
\text { with CIFOR } \\
\text { Other actors such as local government, } \\
\text { ASMINDO, etc. are willing to share } \\
\text { information related to furniture }\end{array}$ & $\begin{array}{l}\text { Market demand drives and overrules } \\
\text { production leading to lower product } \\
\text { quality } \\
\text { - High production cost due to price } \\
\text { increases of raw materials and } \\
\text { transportation costs } \\
\text { - Price of raw material fluctuates and lack } \\
\text { of supply } \\
\text { - Unhealthy competition among actors in } \\
\text { Jepara furniture industry } \\
\text { - Lack of access to affordable capital and } \\
\text { market information }\end{array}$ \\
\hline \multicolumn{2}{|c|}{ External factor } \\
\hline Opportunity & Threat \\
\hline $\begin{array}{l}\text { - Market demand for Jepara furniture is still } \\
\text { high } \\
\text { - Skilled labourers are underutilized }\end{array}$ & $\begin{array}{l}\text { Increased production of similar furniture } \\
\text { products from other districts outside } \\
\text { Jepara } \\
\text { - New competitors from abroad: China, } \\
\text { Vietnam and Malaysia }\end{array}$ \\
\hline
\end{tabular}


FIGURE 6 The roadmap structure

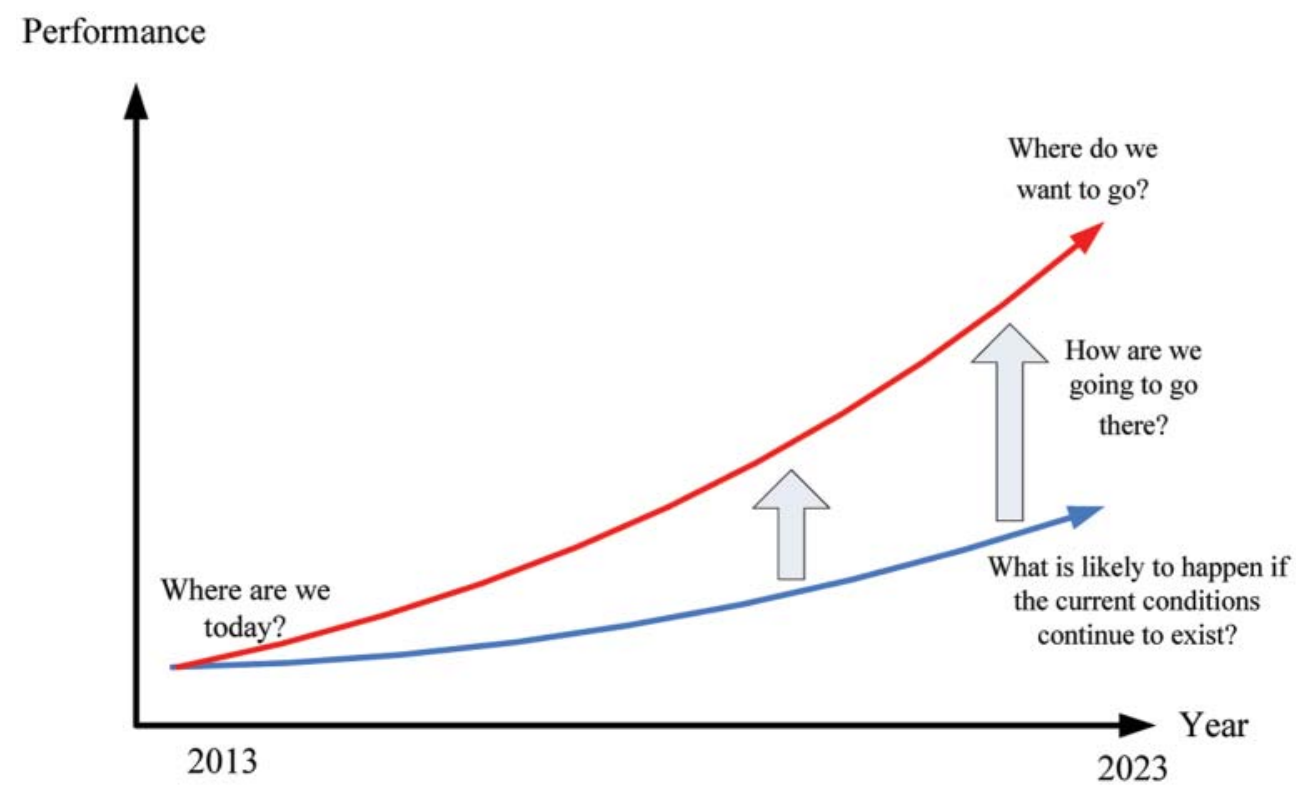

was developed as follows: Introduction, the current picture, projection for the next 10 years, ideal conditions and programs to achieve them. These would be chapters of the roadmap. In other words, the roadmap tried to respond the following: (a) Where are we today? (b) What is likely to happen if the current conditions continue to exist? (c) Where do we want to go? (d) How are we going to get there? Figure 6 shows the conceptual diagram of the roadmap. Y-axis is the furniture industry performance in the sense that the roadmap was designed that aims at improving the performance of furniture industry as well as SMEs in Jepara. On the roadmap produced there are indicators to measure the performance.

The first part, "Where are we today?" included information collected from published sources and describes the geography, land cover and population of Jepara. This is followed by the current situation experienced by furniture producers, wood suppliers, retailers and their value chains. This comprises details on raw materials, trade and marketing, capital flows, credit, global trends, technology and design, national policies, employment and livelihoods, institutions and gender relations. This part provides the objective data and information on the condition of the Jepara District furniture industry. For example, CIFOR research helped identify that female workers are paid less than male workers and yearly capital circulation due to furniture industry in Jepara is $\$ 0.9$ billion.

The second part, "What is likely to happen?" projects the future condition of of raw material supplies, new markets, capital and spatial location of furniture business units. For instance, annual wood demand is currently $864,771,000 \mathrm{~m}^{3}$, and is projected to increase $24 \%$ in the next 10 years. Likewise, capital is also projected to increase more than $30 \%$ annually. Projections were mostly based on historical trends, though sometimes also based on common agreement among APKJ members.
The third part, "Where do we want to go?", describes the situation we hope for in the next 10 years, in terms of raw material supplies, access to capital and markets, human resource needs, infrastructure, institutions and gender. It is projected that the market for Jepara District furniture will grow $7 \%$, in accordance with the national industry growth target of 7\%, outlined in the Masterplan for Acceleration and Expansion of Indonesia's Economic Development (MP3EI) 2011-2025 (Coordinating Ministry for Economic Affairs 2011). To achieve this growth raw material supplies, capital and infrastructure must also grow at comparable rates.

The last part, "How are we going to get there?" outlines programs to achieve the roadmap targets. The programs and targets of raw material supplies, capital, market, human resources, infrastructure, institution and gender in the next 10 years were discussed and written down in the roadmap. The role of stakeholders for each year was discussed and agreed.

The fourth workshop on 17 November 2011 discussed the roadmap draft and finalized it. Participants were welcomed by BAPPEDA. A Central Java Forestry Unit representative outlined the potential of a cloned teak in providing new raw materials with shorter rotations. He stated that stakeholders in Jepara need to work together with forest farmers outside Jepara, such as Wonogiri (Purnomo et al. 2011). A representative from STIENU urged the importance of kinship relationships and informal management of furniture businesses, as well as government support for the furniture industry. A representative from STTDNU suggested public consultation for the roadmap, integration with existing plans, utilization of corporate social responsibilities from private and state-owned companies to provide financial support to small-scale producers, promotion of raw material diversity and adding a creative touch to furniture manufacture. The chairman of ASMINDO stated he was proud of the roadmap, saying he would bring 
this idea to the national level. The FVC team and APKJ considered and noted all suggestions for the roadmap draft. The intention was to work together to improve the roadmap and share the results in a public consultation in early 2012.

The roadmap comprises key solutions for the local government with support from parliament to act together with all stakeholders to improve furniture industry. The key solutions are facilitating domestic and global market penetration; allocating more funding to invest for new furniture design; facilitating SMEs to get TLAS (Timber Legality Assurance System) or in Indonesian known as SVLK (Sistem Verifikasi Legalitas Kayu); strengthening and training for SMEs; building infrastructure for national and global furniture trade such as wood depots and harbors; securing raw materials; and improving participation of female workers in furniture industry. Connecting with national and global markets is key because after all furniture product is buyer driven. New design for furniture is needed to maintain the uniqueness of Jepara furniture as well as to meet market demand. SVLK is needed for entering EU, USA and Australia markets. Capacity building for SMEs to comply with various national and international standard is key for better market penetration and provide more incomes for communities. Women dominate furniture workers but paid less than men due to women entering to low-paid job segments such as sanding and furnishing. Improving women capacity to do more jobs like carving and having their own business is key for better participation in FVC and improving their wages and incomes.

The public consultation was carried out on 28 February 2012 at the fifth workshop. The aim of the event was to introduce the roadmap and find the correct public policy vehicle for it (PERDA or PERBUP). A BAPPEDA representative opened the public consultation by acknowledging the positive impact that the roadmap could have for Jepara. The only concern he had was that the roadmap's targets and deadlines for implementation needed to be clarified. Furthermore, he mentioned that the roadmap would be used for reference for another medium-term district development plan. The FVC team followed by presenting the overall roadmap. All stakeholders were quite happy with the pre-final draft roadmap and provided additional suggestions for further improvement. Discussions also identified that the roadmap was better suited to becoming a PERBUP than a PERDA, although it would be less powerful. PERBUP is under the authority of the District Head, while PERDA needs parliament's approval. This process would take a longer time and is uncertain. The public welcomed the idea of the PERBUP, and BAPPEDA agreed to become the focal point for the process.

\section{The roadmap comprises}

The final roadmap was officially handed over to BAPPEDA on 29 February 2012 in the BAPPEDA office. In receiving the roadmap, BAPPEDA mentioned the possibility of a delay in the process due to (then) imminent local elections for the Jepara Head of District (Bupati). The new Bupati would only function after being formally inaugurated. It was agreed to introduce the final draft roadmap to the newly elected Bupati.

\section{Augmenting the roadmap to political elites and policy} makers

The newly-elected Head of Jepara District (Bupati) met with the FVC team to discuss the roadmap on 13 August 2012. The FVC team and APKJ explained the history of the roadmap development to the Bupati, who was accompanied by highranking staff of the Bupati Office. of the Bupati Office. The Bupati appreciated the roadmap effort and promised it would be part of his program. The Bupati wanted the roadmap to be completed with yearly targets and clearer indicators to ensure the Government of Jepara could easily execute the roadmap.

The FVC team and APKJ carried out a FGD on 20 September 2012 to determine yearly targets for the next 10 years and find appropriate indicators to measure them. During the FGD, in which all key Jepara District actors participated, targets and indicators were developed. Also discussed was how to make the roadmap PERBUP. The roadmap would become the academic text, while the legal decree needed to be formulated in collaboration with the Bupati Office.

The Bupati and district agency representatives received the FVC team on 10 January 2013. The meeting aimed to discuss and update the result of the roadmap document as well as to seek an opportunity to integrate the roadmap into the Jepara District policy. The FVC team explained that the action research had been conducted in 2009-13 in collaboration with Jepara small-scale furniture producers and other stakeholders, such as district government (Pemda), KADIN, ASMINDO and local colleges. Based on a series of workshops and FGDs, participants urged the roadmap document to be proposed as a PERBUP in order to give it stronger authority. During the discussion, BAPPEDA described alternative ways of implementing the roadmap, whether as PERBUP or PERDA, outlining the advantages and disadvantages of both. The Head of Economic Division at the Bupati Office reiterated the importance of the furniture roadmap as a basis for further development; therefore it must become a PERDA to ensure an appropriate budget, a process only executable under the jurisdiction of the local parliament. The meeting decided to propose a PERDA rather than a PERBUP, as a PERDA has more power and a longer timeframe for enforcement. The Bupati suggested the FVC team request a hearing at the Jepara Parliament.

The FVC team was invited by the Jepara House of Parliament to a hearing to present the Roadmap of Jepara District Furniture Industry 2013-2023 on 4 February 2013. The hearing was led by co-chair of the Parliament and involved members of parliament from Commission B on Economics and Industry, local government and local mass media. At the end of the discussion, the Chair drew five conclusions: (a) On behalf of the people of Jepara District, the Parliament expressed their appreciation and gratitude to CIFOR and the FVC team for their research in Jepara, which was then documented in the Roadmap of Jepara District Furniture 20132023; (b) the Parliament requested the local government to follow up on the recommendations in the roadmap document and discuss them with local stakeholders; (c) the Chair of the Parliament gave a mandate to Commission B to discuss 
recommendations in the roadmap document with local government; (d) the Parliament will formulate the roadmap as a parliamentary initiative District Regulation in 2013 (PERDA Inisiatif); and (e) the Parliament requested local government to interpret and integrate programs detailed in the roadmap into the local government development program.

The FVC team received a courtesy visit from Jepara District Parliament (DPRD) members on 26-28 February 2013. Twelve DPRD members came and wanted to learn more about forests and the furniture industry and shared their appreciation for the CIFOR-FVC, including IPB and FORDA work in Jepara. The visit was led by the Deputy Parliament Chairman and Economic Commission Chairman.

\section{Issuance of the PERDA}

Joko Widodo (Jokowi) and Jusuf Kalla won the last general election in Indonesia and were inaugurated on 20 October 2014 as President and Vice-President respectively. This change of power has changed multiple sociological, economic and political dimensions. Jokowi was elected as the 7 th President of Indonesia. Interestingly, he was a forester as well as a furniture businessman. In the past, he was a chairperson of the Indonesia Furniture Association (ASMINDO) in Solo, Central Java. Many people have high expectations that Jokowi will improve the welfare especially of SMEs during his tenure. Strengthening SMEs is among the top priorities of Jokowi's cabinet.

At the same time, Jepara Parliament was more aware of the role and importance of small-scale furniture businesses. When furniture stakeholders intended to transform the Jepara furniture roadmap into legally binding regulation, the parliament accepted this idea and worked on it. It resulted in district law (PERDA) No 2/2014 pertaining to the protection, capacity improvement and development of the furniture industry (PERDA tentang Perlindungan, Pemberdayaan dan Pembinaan Industri Mebel) which was passed by the Jepara Parliament in August 2014 (Government of Central Java Province 2015). This law is based on the furniture industry roadmap that was developed through a multi-stakeholder process facilitated by CIFOR during the period 2009-2013.

This new district law defined new institutional arrangements related to the furniture business in the district of Jepara and beyond. Decision makers are required by law to support the development of small-scale furniture producers and certification of their products. The PERDA is expected to provide a regulatory foundation and government budget to support Jepara District SMEs in marketing, production, legality certification and institutional strengthening. The PERDA has influenced annual Jepara District Plan and budget processes in 2015 and would be realised into the activities on the ground in 2016. The FVC team continued to watch the translation of the roadmap into the district's budgeting and actions and monitor their implementation against the performance of furniture industry and its SMEs.

APKJ, established in 2009, continues to enable its members to influence policy formulation, market access and raw material procurement. Through the business associations i.e. Jepara branch of a new association of Indonesia Furniture and
Craft Association (AMKRI) and ASMINDO the project was able to communicate and influence the Head of Jepara District and key members of the local parliament. ASMINDO and AMKRI are dominated by large furniture enterprises and individuals who possess links (social, economic and political) to Jepara's policy makers.

\section{DISCUSSION}

The discussion presented below distinguishes between the methods adopted during the development of the roadmap, the results achieved and links to theoretical frameworks.

\section{Discussion of method}

The PAR method implemented during roadmap development produced clear outputs and outcomes. This participatory method provided opportunities for everyone, particularly those who are weak and marginalized, to participate in the process. It is common for the government to hire a professional consultant to develop plans. However, common people have limited opportunity to engage in the process and to be counted in future industry development. During the roadmap development, SMEs, represented by APKJ, actively expressed their initiative and ideas drawing on many years $f$ experience, and indeed took the lead on many issues such as improving the local government budget allocation for professional training and trade exhibitions. We ensured at the beginning of the process that the power of APKJ was leveled up vis-à-vis larger actors, by providing them with earlier opportunities to contribute ideas to the roadmap.

The correspondence analysis result provided a clear picture of the position of each stakeholder relative to others in terms of their respective knowledge base, degree of influence and power in, for example, the policy-making process. This made it easier subsequently to navigate and facilitate the discussions and workshops through an improved understanding of power relations, knowledge and formal relationships with each other. The PAR method facilitates a process for all stakeholders to share and learn about the current status of the furniture industry and its future development. A series of workshops provided various actors with continuous learning on the current situation, projected future, their common vision and ideas and how to realize it. Not everybody understood the current situation. Information was distributed and handled by different institutions, e.g. governments, research organizations and scholars. The workshops provided opportunities for information exchange. The projected future made participants aware that they need to act soon to secure their future. More importantly, they needed a common vision, so-called roadmap, to act together. The roadmap incorporates a common belief, future plans and targets for all actors.

The PAR method was successful due to stakeholders' demand driven to the roadmap. Stakeholders wanted to have clear policy guidance on how the furniture industry will be developed in the future. The district government had no guidance except a furniture industry roadmap prepared by the 
national Ministry of Industry. However, policies are broader at the national level, which makes things difficult to implement directly in Jepara. Large companies wanted to know the future direction to address raw material scarcity, appropriate labor conditions and certification requirements. Small-scale producers wanted to know how to market their products in more efficient ways in order to provide greater value added, or to organize themselves to better negotiate with large buyers. NGOs wanted to influence furniture policies in the interests of local communities. Participants were enthusiastic because the roadmap directly touched upon each of their specific interests.

\section{Discussion of results}

The output of the PAR multi-stakeholder process was the roadmap document, which evolved from grassroot-level discussions to reach local political elites. This output was accompanied by clear and strong support from four stakeholder categories i.e. powerful enterprises and offices, policy makers, small-scale enterprises and furniture experts (Figure 4). Likewise, the outputs were both influenced and had influence on all the stakeholders. The four steps in the development of the roadmap were: (a) Workshops at grassroots level co-facilitated by the Jepara small-scale furniture association (APKJ) and FVC team which led to the roadmap initiative and ideas; (b) multi-stakeholder processes in participation with local government, LEs, associations, women enterprises, NGOs and local colleges to produce a roadmap draft, which reflected common interests and goals for all stakeholders; (c) sharing ideas with the Jepara Head of District (Bupati) to produce a roadmap with improvements and endorsements; and (d) hearing with District Parliament members to amend the roadmap, resulting in the local parliamentary initiative that led to a district regulation (PERDA). In other words, outputs and outcomes were achieved iteratively and step by step.

Having a clear mandate from all stakeholders is essential to facilitate a roadmap development process (Awang et al. 2005). Problems and stakeholders must be clearly identified. Every problem has associated stakeholders. Likewise, stakeholders can define common problems. In this case, during the first workshop stakeholders defined the need for the roadmap and its associated stakeholders. This became the basis for the work carried out by the FVC team once all stakeholders had been identified. As data and information can be biased, we ensured stakeholders were involved in data collection and analysis. In essence, CIFOR and the FVC team 'only' facilitated stakeholders to use their own data and conduct their own analyses for use in the roadmap development.

The FVC team was aware that levelling power imbalances are extremely important to ensure weak and poor stakeholders are represented adequately (Purnomo et al. 2003a) including women (Purnomo et al. 2011). In a situation where power imbalances exist and stakeholders need to sit together, powerless stakeholders tend to be less active and less vocal than powerful ones. Therefore, it was decided to support the representation of SMEs by APKJ through various capacitybuilding actions. As a result, during the roadmap development, APKJ actively expressed their concerns and ideas and, indeed, took the lead in many issues, such as improving government budget allocation on training and trade exhibitions. APKJ members are strength in numbers (FAO 2013), which to release their strength to influence their future.

This road development process was time consuming and had to deal with complex situations, as it could not be separated from the dynamic of local politics (Purnomo et al. 2012). At the beginning of this initiative, the FVC project received full support from the ruling Bupati. During the process, the political environment in Jepara District shifted, indicated by a changing regime and a newly elected Head of District. The change led to the replacement of some bureaucrats and officers, in particular, key government agencies. As a result, we had to deal with new leaders as well as new officers in the district agencies we worked with.

Recognizing such changes with such challenges was the best way to sustain the roadmap initiative and keep stakeholders informed on recent progress. This has been an effectively proven strategy, with the newly elected Bupati deliberately interacting with the project team as well as other stakeholders such as APKJ. In fact, the Bupati showed an interest in the roadmap initiative and its relevance to industrial policy development in Jepara District. Likewise, newly appointed officers at particular government agencies echoed their leader and showed enthusiasm for the roadmap.

As the political constellation changed, the team realized that KADIN had not contributed since the beginning of the process, though it played a greater role near the end of roadmap development process. Many KADIN members were allies of the new Bupati. Thus, we immediately invited and involved them in the process. As action research is used to promote social and political transformation (Selener 1997), active learning and acting upon problems are key to successful intervention. KADIN involvement was, in fact, one of the key leverage points of acquiring the Bupati's support.

The importance of bottom-up policy and regulatory reforms and development of regional forestry cooperative to support a farmer afforestation scheme were also suggested by Leys and Vanclay (2010). These reforms can potentially tackle annual \$A2.1 billion trade deficit in Australia for forestry products. The involvement and participation of communities need to be enhanced in the development of sustainable plantation forestry in Australia.

The results can contribute to the achievements of United Nation Sustainable Development Goals or UN-SDGs (UN 2015). Furniture is the most labour intensive industry in forestry and in which the SMEs can still survive. Unlike pulp \& paper as well as plywood industries that are dominated by huge and giant investments, furniture industry can provide livelihoods to millions of people and drive inclusive economic growth. Therefore, sustaining furniture industry will contribute to 8: Promoting inclusive and sustainable economic growth, employment and decent work for all. The research also promotes development-oriented policies that support productive activities, decent job creation, and strengthen 
micro-, small- and medium-sized enterprises as outlined in Section 3 of Goal 8.

The roadmap encourages the uses of legal and certified timber in sourcing timber material for furniture both SMEs and LEs therefore it will reduce environmental costs. The roadmap implementation will contribute to the achievement of Goal 12: Ensure sustainable consumption and production patterns. Legality of timber is proceeded by a mandatory system known as SVLK Indonesia is now negotiating European Union to obtain Forest Law Enforcement, Governance and Trade (FLEGT) license due to the successful implementation of SVLK. The license would allow Indonesia's timber enter the EU easily bypassing strict EU timber regulation requirement. While voluntary certification system for timber can be done through various certification schemes i.e. FSC (Forest Stewardship Council), European Union based PEFC (Program for Endorsement Forest Certification) or Indonesian based LEI (Indonesian Eco-labelling Institute). Likewise, the sustainable wooden furniture industry will provide demand and incentive to growing trees, and therefore contributing to the achievement of Goal 15: Sustainably manage forests, combat desertification, halt and reverse land degradation, halt biodiversity loss.

\section{Discussion of theory}

The roadmap development process was able to engage with a broad array of stakeholders who were each able to communicate their concerns and legitimate interests by raising critical issues facing the furniture industry in Jepara District. Communication is also a way to express their ideas and influence others in the uses of natural resources (Purnomo et al. 2013). They communicated actions to find agreement with others. Each stakeholder communicated specific actions as a way to identify and find agreement with others on actionable solutions. This communicative action was suggested by Habermas (1987) as an effective tool to reach agreement among different actors as people tend to be influenced more by actions than ideas. The decreasing economy and natural resources can be used to enforce feedback to the stakeholders to learn and develop better plans such as roadmap for the future (van Noordwijk et al. 2011).

PAR cannot be directed to fulfil your own agenda and time schedule. PAR can only work well when we have sufficient time and budget to truly recognise various types and interests of stakeholders, balance power of them and facilitate change. Change can be triggered when a stakeholder starting to act to realise their ideas and communicate it to other stakeholders. Waiting for the others' actions first is not recommended. Sometimes the spirit of altruism is necessary to realise collective action (Purnomo et al. 2013).

In this type of consensus-building process, participation of stakeholders and clear motivation to improve the situation are indeed necessary (van Noordwijk et al. 2014). There are a number of ways to contribute from passive participation to self-mobilization (Pretty 1995). The Jepara District roadmap process started with interactive participation where stakeholders participated in a scoping exercise and joint analysis to identify common problems and objectives that ultimately led to clearly defined plans of action. In some cases, the degree of participation advanced to self-mobilization; for example, when APKJ took the initiative to challenge banks' indifferent policy to SMEs by collectively requesting banks to improve the capacity of SMEs to access credit to invest in the furniture industry.

The multi-stakeholder process adopted in the development of the Jepara District Furniture Industry Roadmap enabled CIFOR and the FVC team to recognize and address cross-scale dynamics in the FVC and over time in order to design and implement more effective governance and financing arrangements. The multi-level governance (MLG) of forest resources - as the critical raw material for the furniture industry - involves complex interactions of state, private and civil society actors at various levels, and institutions linking higher levels of social and political organization (Mwangi and Wardell 2012). SMEs and local communities in Jepara District are increasingly connected to global networks and influences. This creates new opportunities to learn and address problems but may also introduce new pressures and risks. The multi-year roadmap process facilitated a more complex approach to MLG which led to a better understanding amongst stakeholders of how policies work as instruments of governance and the organization of SMEs and communities within systems of power and authority.

\section{CONCLUSIONS}

The participatory multi-stakeholder process successfully produced a PERDA, a binding local law, that issued by the Jepara District parliament. Local demand for support in developing the roadmap and engagement of four groups of distinct stakeholder groups were critical to ensure that the process met expectations. During the process many actors communicated and learned how to analyze the current situation, future projections, agree on a common vision and actions needed to realize their ten year objectives. The roadmap development process strengthened small-scale producers' bargaining positions and improved trust with local government authorities.

The Jepara District case study also highlights how forest products often exhibit an intricate mix of trade flows caused by different use values and the dynamics of demand patterns - locally, regionally and globally. The relative importance of different flows raises important questions in relation to the sustainability of raw material supplies and the resilience of local small-scale production systems based on longestablished patterns of processing and trading. Heretofore, priority has been given to the prospects for chain upgrading invariably linked to the broader debate on development via participation in global markets as an (assumed) more viable alternative to reliance on local or regional domestic markets. The Jepara District roadmap process redresses this debate in terms of the broad stakeholder recognition of the importance of different end-markets be they national, regional or global. 
Additional research is needed to identify new opportunities to access affordable credit with more flexible repayment schedules for SMEs, policies to promote women-led SMEs and how to improve employment conditions for women in the Jepara furniture industry.

\section{ACKNOWLEDGEMENTS}

Opinions expressed herein are solely those of the authors and do not necessarily reflect the official views of the authors' affiliations. The authors thank ACIAR for supporting research on 'Mahogany and teak furniture: action research to improve value chain efficiency and enhance livelihoods (FST/2007/119, 2008-2013)' and DFID-UK for supporting furniture value chain research (2014-2017). The authors also thank the project partners: Faculty of Forestry, Bogor Agricultural University and Forest Research (IPB) and Forestry Research, Development and Innovation Agency (FORDA), Ministry of Environment and Forestry, Indonesia. The valuable suggestions made by anonymous referees is gratefully acknowledged.

\section{REFERENCES}

ACHDIAWAN, R., PUNTODEWO, A. 2011. Livelihood of furniture producers in Jepara, Furniture Value Chain Project Annual Report 2011, Center for International Forestry Research, Bogor.

AWANG, S., PURNOMO, H., WARDHANA, W., GUIZOL, P., LEVANG, P., SITORUS, S., MURTIYANTO, N. and SUSANTO, Y. 2005. Levelling the playing field. Improving partnership in pulp forest plantation to benefit the poor reduce conflict: LPF project, South Sumatra case study. Project report. Bogor: EU, CIRAD, CIFOR.

COLFER, C.J.P. 2005. The Complex Forest: Communities, Uncertainty, and Adaptive Collaborative Management, Washington DC, Resources for the Future and CIFOR, 370 pp.

COMTRADE. 2016. United Nations Commodity Trade Statistics Database. New York: United Nations. http:// comtrade.un.org/db/dqBasicQueryResults.aspx $? \mathrm{y}=2014$ $\& \mathrm{rg}=2 \& \mathrm{px}=\mathrm{S} 3 \& \mathrm{cc}=8215 \& \mathrm{r}=360$ (Accessed 1 July 2016).

COORDINATING MINISTRY FOR ECONOMIC AFFAIRS. 2011. Acceleration and Expansion of Indonesia Economic Development 2011-2025, Coordinating Ministry for Economic Affairs, Republic of Indonesia, Jakarta.

EWASECHKO, A.C. 2005. Upgrading the Central Java Wood Furniture Industry: A Value-Chain Approach, ILO, Manila.

[FAO] FOOD AND AGRICULTURE ORGANIZATION. 2013. Strength in Numbers: Effective forest producer organization, FAO, Rome.

GREENACRE, M.J. 1993. Biplots in correspondence analysis. Journal of Applied Statistics 20: 2251-2269.

GOVERNMENT OF CENTRAL JAVA PROVINCE. 2015. Jepara District Law (PERDA) No. 2 Year 2014, Semarang, Indonesia.
GOWER, C. and HAND, D.J. 1996. Biplots, Chapman \& Hill, London, $277 \mathrm{pp}$.

HABERMAS, J. 1987. The Theory of Communicative Action. Volume 1: Reason and the Rationalization of Society, Translated by T. McCarthy, Polity Press, Cambridge, $562 \mathrm{pp}$.

HAN, X., WEN, Y. and KANT, S. 2009. The global competitiveness of the Chinese wooden furniture industry. Forest Policy and Economics 11(8): 561-9.

[ITTO] INTERNATIONAL TIMBER TRADE ORGANIZATION. 2006. International Timber Trade Organization. Tropical Timber Market Report 11(15). ITTO, Yokohama, Japan.

KOLLERT, W. and CHERUBINI, L. 2012. Teak Resources and Market assessment 2010. FAO Planted Forests and Trees Working Paper FP/47/E. FAO, Rome, http://www. fao.org/forestry/plantedforests/67508@170537/en/ (Accessed 6 January 2016).

LEYS, A.J. and VANCLAY J.K. 2010. Land-use change conflict arising from plantation forestry expansion: Views across Australian fence-lines. International Forestry Review 12(3): 256-269.

MWANGI, E. and WARDELL, A. 2013. Multi-level governance of forest resources. International Journal of the Commons 7(2): 339-343.

PRETTY, J.N. 1995. Regenerating Agriculture: Policies and Practice for Sustainability and Self-Reliance. Earthscan, London. 320 pp.

PURNOMO, H., SUYAMTO, D. and IRAWATI, R.H. 2013. Harnessing the climate commons: an agent-based modelling approach to making REDD+ work. Mitigation and Adaptation Strategies for Global Change 18: 471-489,

PURNOMO, H., SUYAMTO, D., ABDULLAH, L. and IRAWATI, R.H. 2012. REDD+ actor analysis and political mapping: an Indonesian case study. International Forestry Review 14(1): 74-89.

PURNOMO, H., YASMI, Y., PRABHU, R., HAKIM, S., JAFAR, A. and SUPRIHATIN. 2003a. Collaborative modeling to support forest management: qualitative systems analysis at Lumut Mountain Indonesia. Small-scale Forest Economics, Management and Policy 2(2): 259-275.

PURNOMO, H., YASMI, Y., PRABHU, R., YULIANI, L., PRIYADI, H. and VANCLAY, J.K. 2003b. Multi-agent simulation of alternative scenarios of collaborative forest management. Small-scale Forest Economics, Management and Policy 2(2): 277-292.

PURNOMO, H. and MENDOZA, H. 2011. A system dynamics model for evaluating collaborative forest management: a case study in Indonesia. International Journal of Sustainable Development \& World Ecology 18(2): 164176.

PURNOMO, H., ARUM, G.S., ACHDIAWAN, R. and IRAWATI, R.H. 2012. Rights and wellbeing: an analytical approach to global case comparison of community forestry. Journal of Sustainable Development 5(6): 35-48.

PURNOMO, H., IRAWATI, R.H., FAUZAN, A.U. and MELATI, M. 2011. Scenario-based actions to upgrade small-scale furniture producers and their impacts on 
women in Central Java, Indonesia. International Forestry Review 13(2): 152-162.

SELENER, D. 1997. Participatory Action Research and Social Change. Cornell Participatory Action Research Network, Cornell University, Ithaca NY, USA, 358 pp.

SITUMORANG, A.W. and KARTODIHARDJO, H. 2013. Participatory Governance Assessment: The 2012 Indonesia Forest, Land, and REDD+ Governance Index. UNDP, Jakarta, Indonesia, http://www.undp.org/content/dam/ indonesia/docs/envi/PG (Accessed 25 July 2016).

UNITED NATIONS. 2015. Resolution adopted by the General Assembly on 25 September 2015: Transforming our world: the 2030 Agenda for Sustainable Development (70/1). UN General Assembly, http://www.un.org/ga/ search/view_doc.asp?symbol=A/RES/70/1\&Lang=E (Accessed 20 April 2016)
VAN NOORDWIJK, M., AGUS, F., DEWI, S. and PURNOMO, H. 2014. Reducing emissions from land use in Indonesia: Motivation, policy instruments and expected funding streams. Mitigation and Adaptation Strategies for Global Change 19(6): 677-69.

VAN NOORDWIJK, M., LUSIANA, B., VILLAMOR, G., PURNOMO, H. and DEWI, S. 2011. Feedback loops added to four conceptual models linking land change with driving forces and actors. Ecology and Society 16(1): r1. [online]. Accessed 20 April 25, 2016. http://www. ecologyandsociety.org/vol16/iss1/resp1/ (Accessed 10 February 2016).

YOSHINO, N. and TAGHIZADEH-HESARY, F. 2015. Analysis of credit ratings for small and medium-sized enterprises: Evidence from Asia. Asian Development Review 32(2): 18-37. 


\section{ANNEXES}

ANNEX 1 Stakeholders of Jepara furniture industry

\begin{tabular}{|c|c|c|c|c|}
\hline No & Institution & Abbreviation & Role & Type \\
\hline 1 & BAPPEDA & $\begin{array}{l}\text { Regional Planning and Development } \\
\text { Board }\end{array}$ & Coordinate district plan development & Government \\
\hline 2 & KADIN & Chamber of Commerce and Industry & $\begin{array}{l}\text { Coordinate business and commerce } \\
\text { activities }\end{array}$ & Private sectors \\
\hline 3 & ASMINDO & $\begin{array}{l}\text { Furniture Industry and Handicraft } \\
\text { Association }\end{array}$ & Synchronize furniture business & Private sectors \\
\hline 4 & FEDEP & $\begin{array}{l}\text { Forum for Economic Development and } \\
\text { Employment Promotion }\end{array}$ & $\begin{array}{l}\text { Forum discussion of economic } \\
\text { development }\end{array}$ & $\begin{array}{l}\text { Multi-stakeholder } \\
\text { forum }\end{array}$ \\
\hline 5 & HIPMI & $\begin{array}{l}\text { Indonesian Young Entrepreneurs } \\
\text { Association }\end{array}$ & Associate youth entrepreneurs & Private sectors \\
\hline 6 & APKJ & $\begin{array}{l}\text { Jepara Furniture Small-scale Producer } \\
\text { Association }\end{array}$ & Associate small-scale producers & Private sectors \\
\hline 7 & HPKJ & Jepara Wood Trader Association & Associate wood traders & Private sectors \\
\hline 8 & STIENU & $\begin{array}{l}\text { Higher School of Economics Nahdatul } \\
\text { Ulama }\end{array}$ & College for economy & College \\
\hline 9 & STTDNU & $\begin{array}{l}\text { Higher School of Design Technology } \\
\text { Nahdatul Ulama }\end{array}$ & College for furniture design & College \\
\hline 10 & SMIK & High School & School for wood craft and technology & School \\
\hline 11 & DPRD Komisi B & District Parliament, Commission B & Represent people & Parliament \\
\hline 12 & ASEPHI & $\begin{array}{l}\text { Handicraft Exporter and Producer } \\
\text { Association }\end{array}$ & Associate for exporting & Private sectors \\
\hline 13 & FRK & Clusters Discussion Forum & Forum for furniture discussion & $\begin{array}{l}\text { Multi-stakeholder } \\
\text { forum }\end{array}$ \\
\hline 14 & IWAPI & $\begin{array}{l}\text { Indonesian Women Entrepreneur } \\
\text { Association }\end{array}$ & Associate women entrepreneur & Private sectors \\
\hline 15 & INDAG & District Industry and Trade Office & $\begin{array}{l}\text { Execute government program on } \\
\text { industry and trade }\end{array}$ & Government \\
\hline 16 & Dinas UKM & District Small-scale Enterprises Office & $\begin{array}{l}\text { Execute government program on } \\
\text { Cooperation and small-scale enterprises }\end{array}$ & Government \\
\hline 17 & DISHUT & District Forestry Office & $\begin{array}{l}\text { Execute government program on } \\
\text { forestry }\end{array}$ & Government \\
\hline 18 & PERHUTANI & State Owned Forest Enterprise & State owned forest company in Java & Government \\
\hline 19 & $\begin{array}{l}\text { LAKPESDAM } \\
\text { NU }\end{array}$ & $\begin{array}{l}\text { Human Resources Research and Devel- } \\
\text { opment Agency of Nahdatul Ulama }\end{array}$ & Channel people voice & NGO \\
\hline 20 & DRD & District Research Council & Research at local level & NGO \\
\hline 21 & Bupati Office & & Head of Jepara Government & Government \\
\hline
\end{tabular}

